УДК 622.331.1:662.819

\title{
ОБҐРУНТУВАННЯ ТЕХНОЛОГІЇ КОМПЛЕКСНОЇ ПЕРЕРОБКИ ТОРФУ НА ПАЛИВО З ВИЛУЧЕННЯМ ГУМІНОВОЇ СКЛАДОВОЇ
}

Корінчук Д.М., канд. техн. наук

Інститут технічної теплофізики НАН України, вул. Желябова, 2а, м.Київ, 03680, Україна

Розглянуто шляхи поєднання технології отримання гумінових речовин та виробництва композиційного палива. Обгрунтовано енергоефективну схему виробництва композиційного палива. Запропоновано методи розрахунку вмісту складових палива.

Бібл. 3, рис. 5.
Ways combination technology of технологии получения гуминовых humic substances and manufacture веществ и производства композици- composite fuel were considered. онного топлива. Обоснованно энер- Energy efficient composite fuel гоэффективную схему производства production scheme was proposed. композиционного . Предложены ме- Methods for calculating fuel тоды расчета содержания компонен- component content was presented.

Ключові слова: фрезерний торф, гумінові речовини біомаса, композиційне паливо.

ГР - гумінові речовини;

В умовах постійного росту цін на викопні палива та високої залежності України від імпортованого природного газу, торф'яні ресурси представляють собою привабливу альтернативу традиційним енергоносіям. В той же час суттєва потреба аграрного сектору в гумінових добривах вимагає побудови спеціалізованих виробництв, спрямованих на виготовлення гуматів. В межах існуючої економічної кризи розв'язання останньої задачі вкрай ускладнене. Інтегрування технології вилучення гумінової речовин (ГР) 3 торфу на торфобрикетному заводі (ТБ3) 3 малими інвестиціями дозволить реалізувати комплексну переробку торфосировини в межах одного підприємства на паливо та добрива [1-4]. На користь вказаної технології грає те, що вирішується задача енергетичних витрат процесів зневоднення добрив за рахунок торф'яного палива. В той же час отримання однієї тони сухих гумінових речовин 3 торфу призводить до утворення $8 . .8,5$ т торф'яного залишку екстракції 3 вологістю біля 80 \%, який можна використовувати на ТБЗ для отримання торф'яного палива. Постає питання раціонального поєднання зазначених технологій.

Метою статті є обгрунтування технологій
ТБЗ - торфобрикетний завод.

комплексної переробки торфу на паливо 3 вилученням гумінової складової.

Основні задачі статті:

1) розробити та проаналізувати можливі шляхи енергетичного використання залишку після екстракції в циклі ТБЗ;

2) обгрунтувати енергоефективну схему поєднання технологій екстракції та виробництва торфопалива на ТБЗ;

3) обгрунтувати методику виведення показників композиційного палива за зольністю та теплотою згоряння на нормований рівень.

За базову технологію взято технологічну схему Семенівського ТБЗ Чернігівської області 3 можливістю виробництва композиційного палива (рис. 1) [3] .

Автором запропоновано залишок після екстракції повертати в цикл переробки на паливо одним 3 трьох напрямків:

1) залишок може бути змішаний з торф'яною сушонкою;

2) залишок може бути повернуто в технологічний цикл заводу на вхід до сушарки;

3) залишок може бути вивезено на поля для проведення польового сушіння.

Для обгрунтування кожного 3 напрямків 
проведено серію досліджень, метою яких була перевірка можливості реалізації напрямку без зниження показників торф'яного палива.

Перший напрямок, а саме змішування залишку з торф'яною сушонкою, ускладнений через відсутність обладнання, здатного рівномірно змішати вологий торф'яний залишок та сухий пиловидний торф. Діапазон варіювання залишку в торф'яній суміші, виходячи 3 досліджень міцності та щільності брикету, становить не більше 7 \%. Відповідно, ця технологія хоча й найменш енергозатратна, але - недоцільна. Другий напрямок (рис. $2 a, \sigma$ )-цеповернення залишкув технологічний цикл торфобрикетного заводу на вхід до сушарки, технологічно просто реалізується подачею залишку в живильник сушарки в співвідношенні з фрезерним торфом до 30 \%.
Суміщення процесу подрібнення 3 сушінням дозволяє рівномірно розподілити залишок в об'ємі сушонки. Однак дослідження кінетики сушіння показали суттєве подовження часу зневоднення суміші через підвищену понаднормовану вологість. Хоча в сушарці наявність гравітаційної сепарації часток на висхідній ділянці забезпечує більший час перебування вологих часток в зоні сушіння, але згідно технічних іспитів сушарки 3 шахтним млином [1] вона нездатна висушити частки 3 вологістю більше 50 \% до необхідних для пресування 15 \%. В результаті вологорізниці можливе тріщіноутворення в брикеті, зменшення гідрофобних властивостей та 3 часом руйнування [3].

Слід врахувати, що на зневоднення сировини 3 підвищеною вологістю буде витрачена

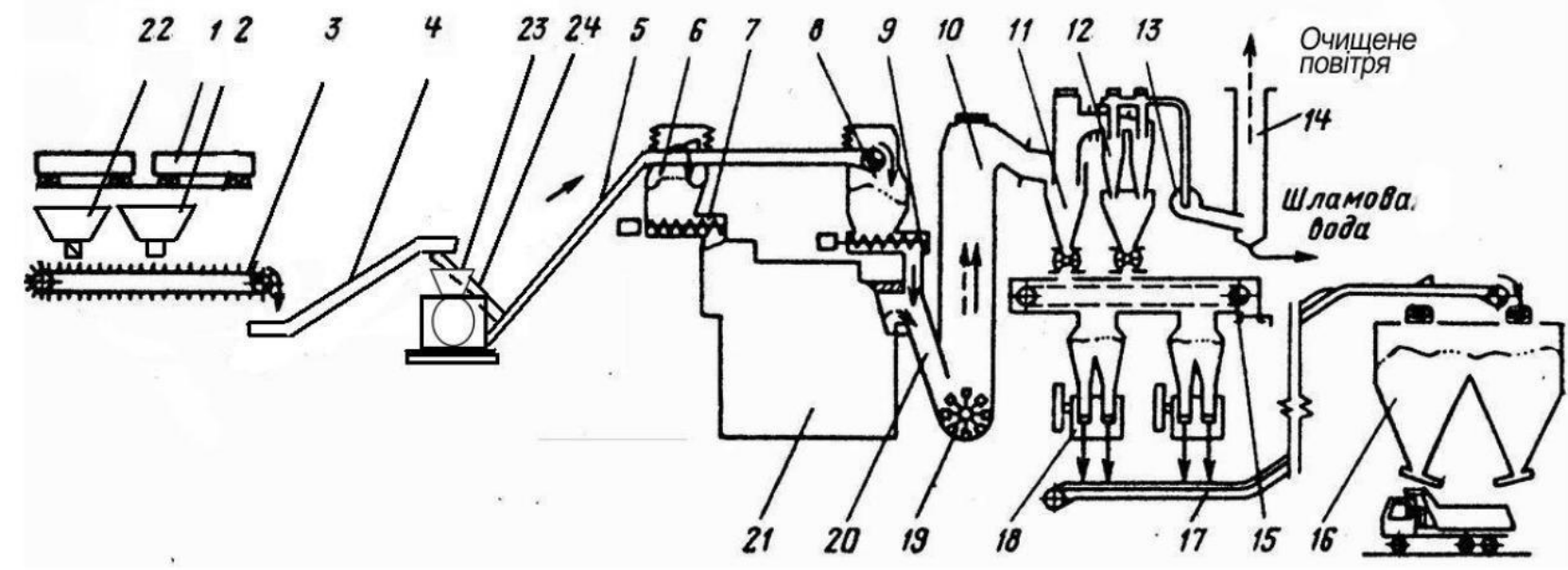

Рис. 1. Технологічна схема заводу виробництва композиційних брикетів.

1 -вагон; 2, 22 - прийомний бункер; 3 -транспортер; 4, 5, 17, 24 -стрічковий конвеср;

6-бункер топки; 7, 9- гвинтовий жсивильник; 8-бункер сушарки; 10 - сепараційна шахта;

11, 12 - циклон; 13 - вентилятор; 14 - скрубер; 15 -розподільний конвеєр; 16 - бункер брикетів;

18 - штемпельний прес; 19 - шахтний млин; 20 -рукав; 21 - топка, 23 - дробарка;

24 - обвідний рукав.

додаткова енергія, що підвищить питомі витрати на сушіння торф'яної сушонки. Для отримання тони брикетів необхідно тону висушеного торфу або 1,7 т фрезерного торфу 3 вологістю $50 \%, 3$ якого попередньо необхідно видалити 700 кг вологи. При домішці до торф'яної суміші $30 \%$ залишку з вологістю 80 \% ми вводимо в сушарку додатково 570 кг вологи, що веде до підвищення теплових витрат на тону брикетів на
2,18 ГДж. При витратах 4,84 ГДж/т висушеного торфу технологія являється суттєво енерговитратною.

Третій напрямок (рис. 2 г, d), включає вивезення торфу на торфородовище для польового сушіння. В Україні традиційною є схема видобування фрезерного торфу із застосуванням скреперно-бункерного видобувного комплексу. Цей спосіб порівняно з іншими має найменші 
трудомісткість і собівартість продукції. Торф'яні родовища для розробки фрезерним способом попередньо осушують і на їх поверхні підготовляють експлуатаційні (виробничі) площі.

Цикл видобування фрезерного торфу включає п’ять операцій [3]:

1) фрезерування торфового покладу на глибину 20 см за допомогою фрезерного барабана, що агрегується трактором, з метою подрібнення поверхні і утворення розстилу торфової крихти;

2) ворушіння розстилу для інтенсифікації сушіння частинок торфу;

3) валкування, тобто згрібання частинок торфу з розстилу у валки;

4) збирання торфу з валка у скрепер, а в подальшому - в бункер торфозбиральної машини, транспортування до штабеля і розвантаження фрезерного торфу у навали біля підніжжя штабеля;

5) штабелювання - переміщення фрезерного торфу 3 навалів у штабель, надання штабелю правильної, раціональної форми.

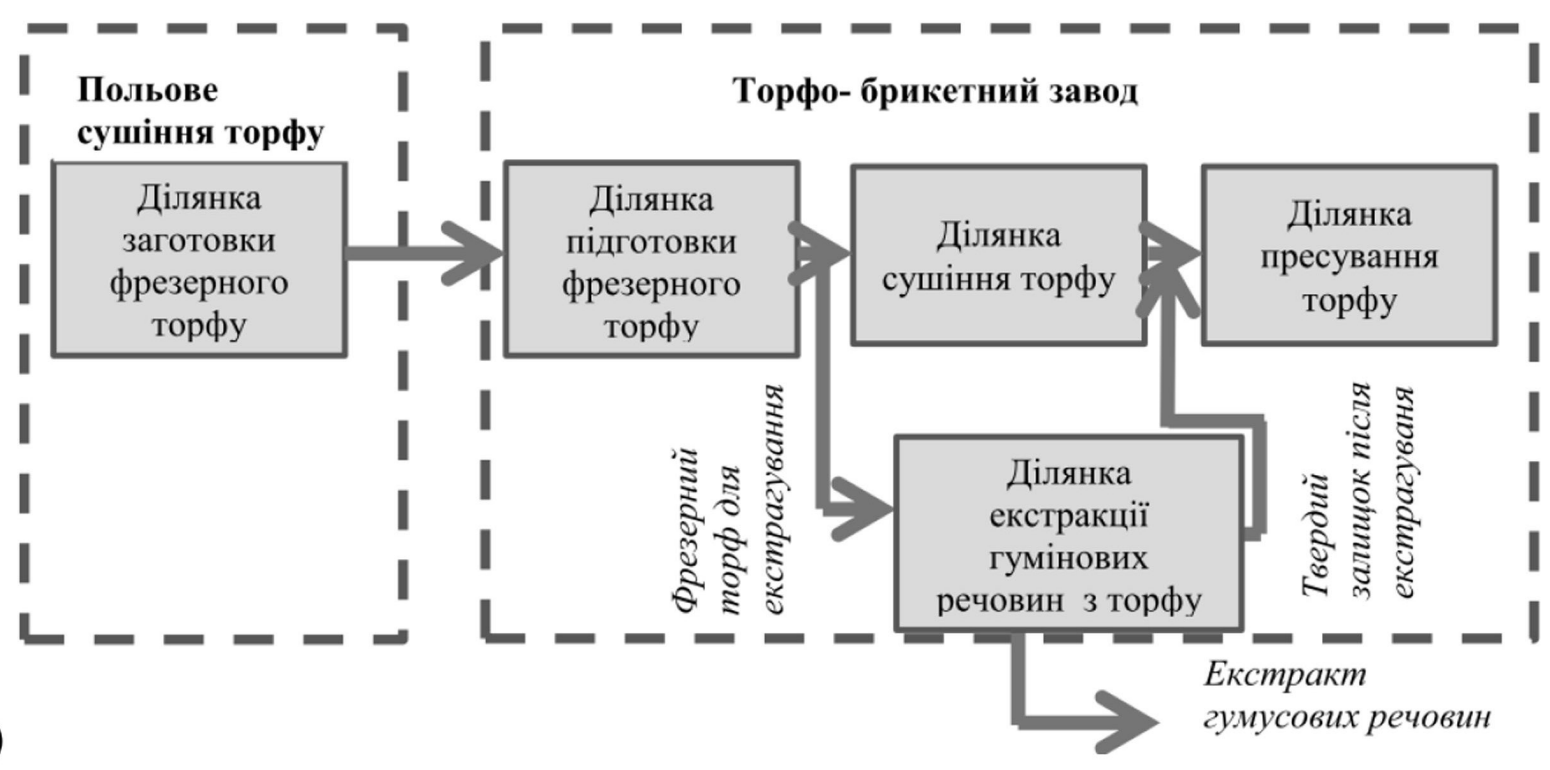

\section{a)}

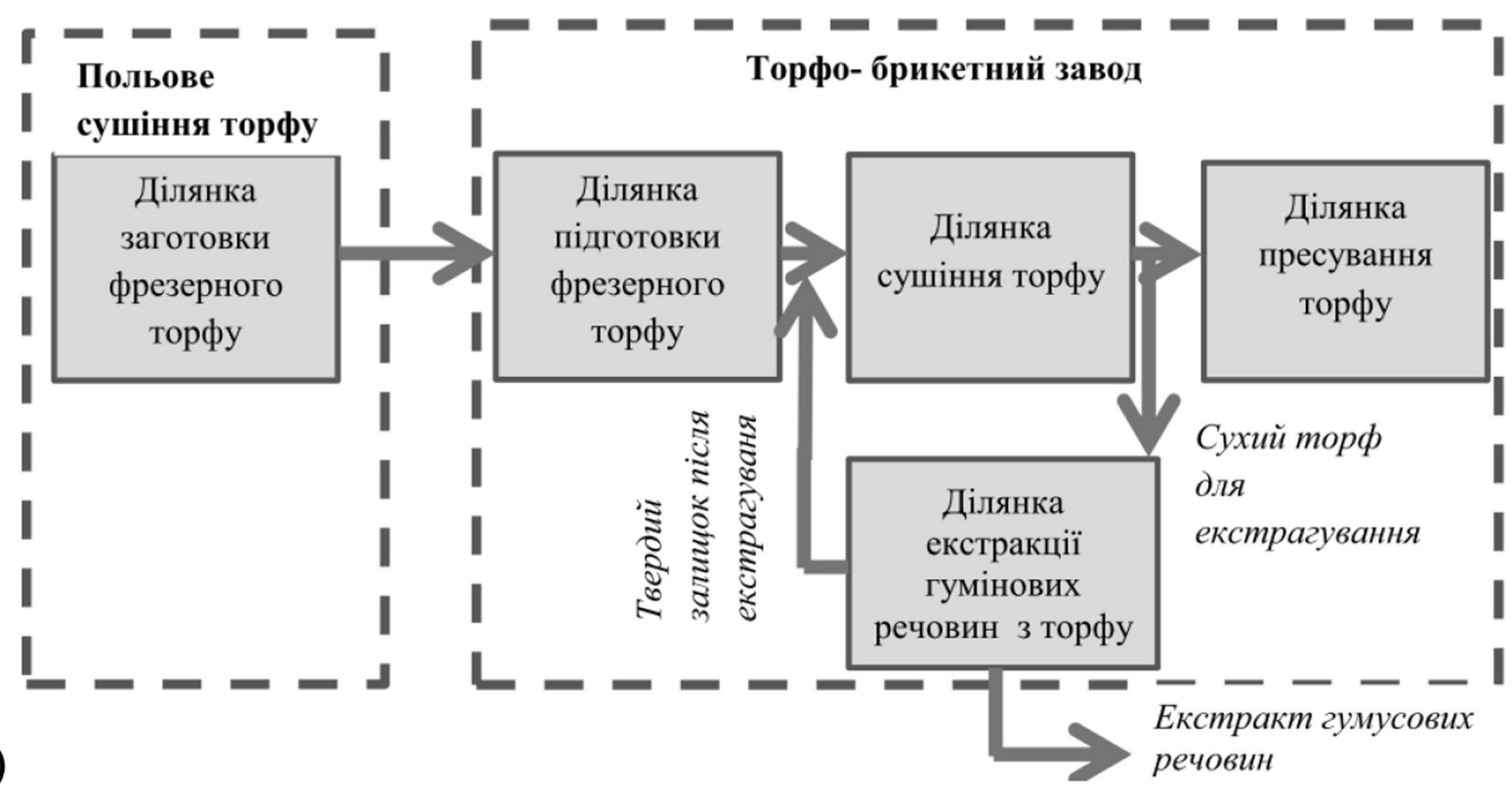



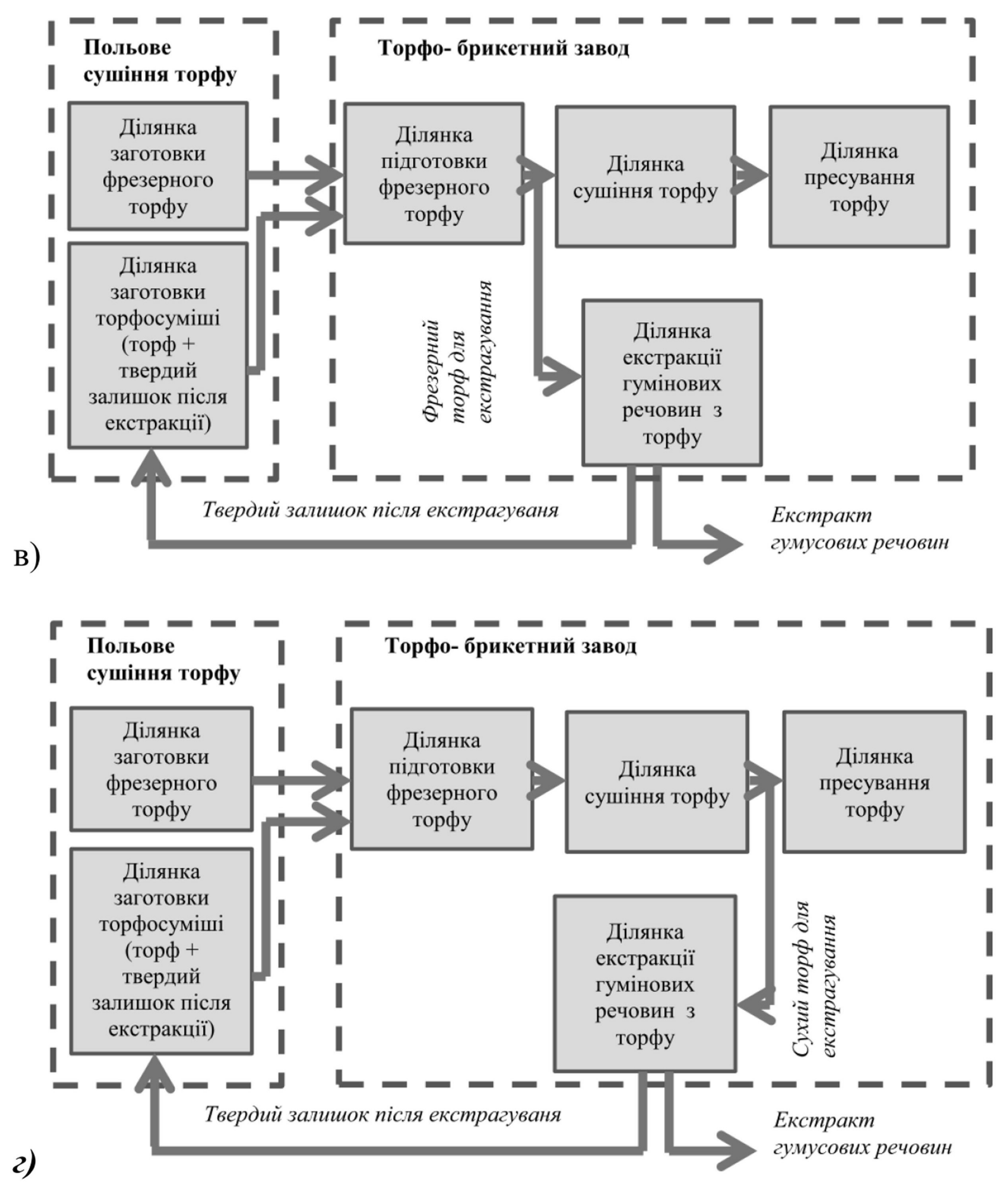

Рис. 2. Блок-схема комплексної переробки торфу на паливо.

а) з екстракцією ГР з фрезерного торфу та примусовим суиінням твердого залишку;

б) з екстракцією ГР з сухого торфу та примусовим сушінням твердого залишку;

в) з екстракцією ГР з ррезерного торфу та польовим сушінням твердого залишку;

2) з екстракцією ГР з сухого торфу та польовим сушінням твердого залишку. 
Закінчений комплекс робіт від фрезерування до збирання готової продукції - технологічний цикл; його тривалість 1...2 дні. Після збирання торфу на експлуатаційних площах проводиться нове фрезерування і цикл повторюється. За сезон видобутку торфу в залежності від якісної характеристики розроблюваного шару поклади, використовуваного обладнання та погодних умов проводиться $10 . .50$ циклів. Розробка експлуатаційних площ виробляється за 5...15 років залежно від початкової товщини пласта i величини залишкового шару, необхідного для подальшого використання вироблених торф'яних родовищ. Фрезерний спосіб видобутку торфу застосовується на покладах всіх типів без обмеження за ступенем розкладання і вмісту залишків деревини; вологість фрезерованого шару покладу низинного типу не перевищує 79...82 \%.

Залишок торфу після екстрагування центрифугується. Вологість його знижується для 80 \%, відповідно він містить таку саму вологість як торф у покладі і може підлягати циклу переробки аналогічному для отримання фрезерного торфу. Транспортування торф'яного залишку на поле може бути організована саморозвантажувальними вагонами типу ТСВ-6. При густині $900 \ldots 940$ кг $/ \mathrm{M}^{3}$ його структура аналогічна торфу у покладі густина якого коливається в межах 840...1000 кг/м ${ }^{3}$. Технічно найскладнішою операцією $є$ розподілення залишку по покладу торфу. Вона реалізується шляхом розсунення відвалу за допомогою грейдера. Точність розподілу грунтів за допомогою грейдера становить \pm 2 см. Як зазначалося вище, гранична співвідношення у торфосуміші повинно становити $30 \%$ вмісту залишку після екстрагування. Що становить шар висотою 6 см. Приймемо середнє значення шару $4 \pm 2 \mathrm{~cm}$, що відповідає вмісту залишку в торф'яній суміші $20 \pm 10 \%$. Це дозволяє отримати суміш залишку та вихідного торфу заданого складу. Основні стадії переробки наведені на рис. 3.

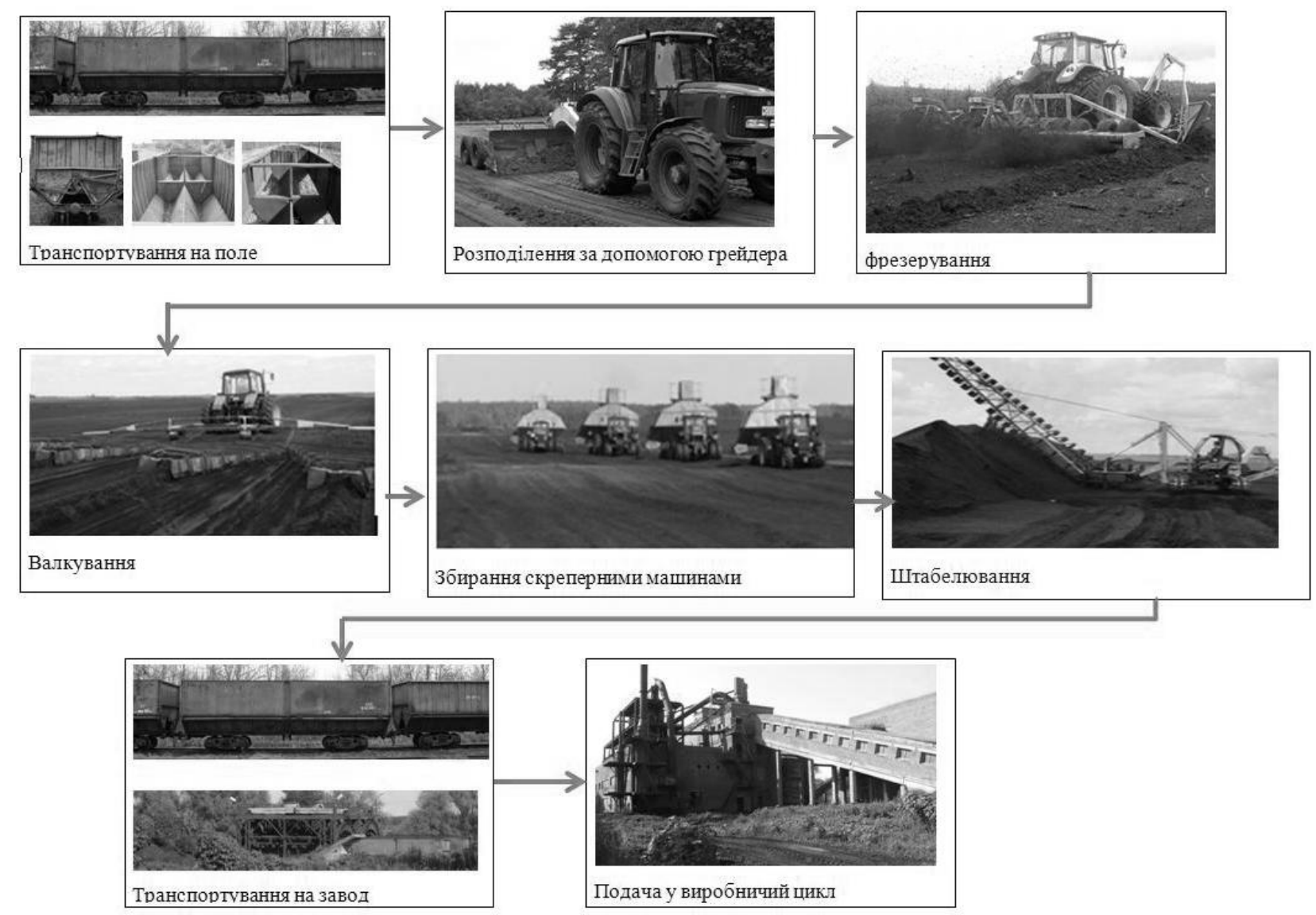

Рис. 3. Основні стадї̈ польового сушіння торф'яного залишку після екстракції. 
Виведення показників композиційного палива за зольністю та теплотою згоряння на нормований рівень виконується шляхом введення в суміш деревинної біомаси, вміст якої не повинен перевищувати 40 \%.[3]. Нормоване значення для зольності торфобрикетів не повинно перевищувати $23 \%$ за ДСТУ 2042. Зольність деревинної біомаси не перевищує $2 \%$, відповідно зольність торфосуміші до введення в неї $40 \%$ біомаси повинна не перевищувати $37,5 \%$, що дозволить зменшити зольність композиції до нормованого рівня. За результатами дослідження зольності для торф'яного залишку після екстракції ï значення коливалося в межах $15 \ldots 25$ \%. Мінімальну кількість деревинної біомаси, яку необхідно ввести в композицію можна розрахувати за формулою, яка враховує пропорційне зменшення зольності палива до заданого рівня при внесенні до нього складової з меншою зольністтю:

$X_{\partial}=100 \frac{A_{\kappa c m}^{c}-A_{m}^{c}}{A_{\kappa c m}^{c}-A_{\partial}^{c}}$,

де $X_{\partial}$ - масовий вміст деревини в суміші, $\% ; A^{c}{ }^{c}$, $A^{c}{ }^{\prime}, A^{c}{ }_{m}$, - відповідно зольність на суху масу торф'яної суміші, деревини чи іншої біомаси та максимально припустима для торф'яного брикету, \%.

Теплота згоряння торф'яного брикету не нормується, але являється якісним показником. Для торф'яних брикетів теплота згоряння становить 15,5 МДж/кг, або 17,6 МДж/кг на суху масу [3], теплота згоряння деревини на суху масу становить 19 МДж/кг [3], а значення теплоти згоряння торф'яного залишку після екстракції, згідно проведених випробувань, обернено пропорційні ступеню вилучення гумінової складової і коливаються в межах 15...17 МДж/кг [4].

Кількість деревинної біомаси, яку необхідно додати у композиційну суміш для підвищення теплоти згоряння може бути розрахована за формулою, яка аналогічно формулі (1) враховує пропорційне підвищення теплоти згоряння палива до заданого рівня при внесенні до нього складової з більшою калорийністтю:

$$
X_{\partial}=\frac{Q_{\kappa c m}^{c}-Q_{m}^{c}}{Q_{\kappa c m}^{c}-Q_{\partial}^{c}},
$$

де $Q^{c}{ }_{\text {ксm }}, Q^{c}, Q_{m}^{c}$ - відповідно теплота згоряння на суху масу торф'яної суміші, деревини чи іншої біомаси та вихідного торфу, МДж/кг. Теплота згоряння на суху масу вихідного торфу приймають $Q_{m}^{c}=17,6$ МДж/кг, інші показники визначають експериментально.

За наведеною формулою (2) побудовано графічну залежність рис. 4, що дозволяє визначити мінімальний вміст деревинної біомаси, яку треба додати до композиції для забезпечення теплоти згоряння на рівні 3 торфобрикетами. Наприклад, якщо теплота згоряння торфосуміші на суху масу буде становити 17 МДж/кг, то вміст деревинної складової в брикеті не повинен бути менше $30 \%$.

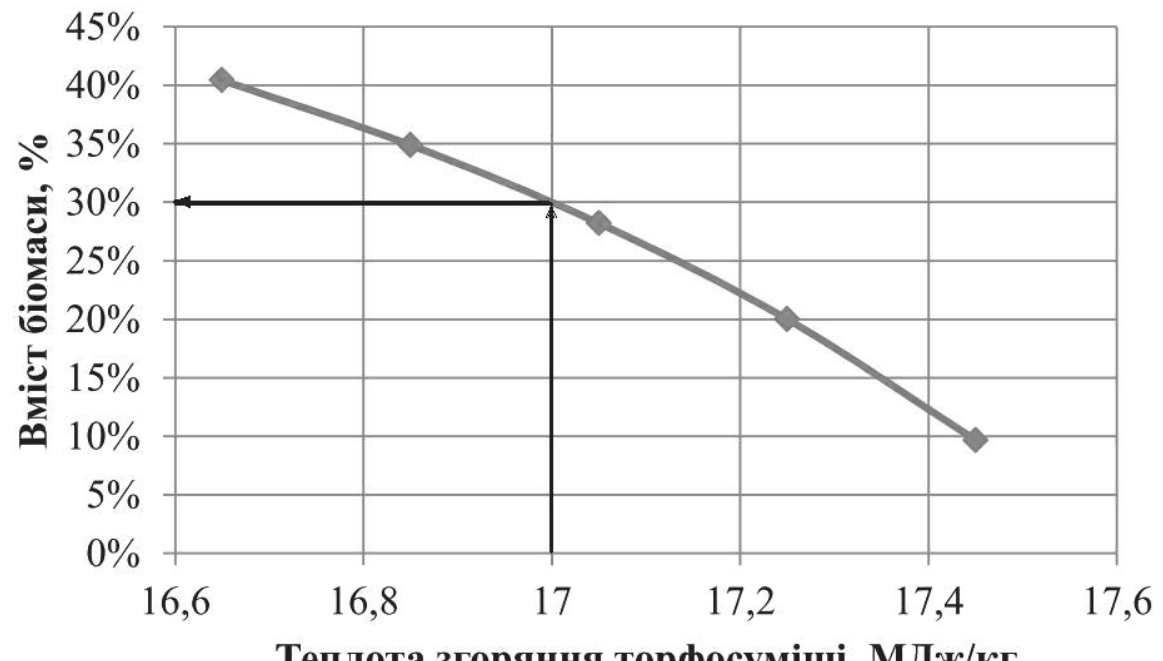

Рис. 4. Розрахунок вмісту деревинної біомаси у торфосуміші для підвищення теплоти згоряння брикетів до нормованого значення. 
3 графіку видно, що при застосуванні композиції з домішкою деревини теплота згорання торф'яної суміші не повинна бути менше 16,75 МДж/кг.

Для врахування вмісту торф'яного залишку після екстракції перетворимо залежність (2) ввівши в неї вираз для розрахунку теплоти згоряння торф'яної суміші:

$$
Q_{\kappa c m}^{c}=\left(Q_{m}^{c}\left(100-X_{\text {зал }}\right)-Q_{\text {зал }}^{c} X_{\text {зал }}\right) / 100,
$$

та отримаємо:

$$
X_{\partial}=\frac{X_{\text {зал }}\left(Q_{m}^{c}-Q_{\text {зал }}^{c}\right)}{Q_{m}^{c}-Q_{\partial}^{c}+\left(Q_{m}^{c}-Q_{\text {зал }}^{c}\right) X_{\text {зал }} / 100},
$$

де $X_{\text {д }}$ масовий вміст деревини в композиції , \%; $X_{\text {зал }}$ - масовий вміст торф'яного залишку після екстракції в торфосуміші, \%; $Q_{\text {зал }}^{c}$ - теплота згоряння торф'яного залишку після екстракції, МДж/кг.

За наведеною формулою (4) побудовано номограму рис. 5, що дозволяє визначити мінімальний вміст деревинної біомаси, яку треба додати до композиції при заданому вмісті торфозалишку в торфосуміші та його теплоті згоряння на суху масу. Досягти потрібного рівня теплоти згоряння брикету можна зменшивши вміст залишку або збільшивши вміст біомаси в композиції. Узагальнюючи весь комплекс досліджень видно (рис. 5), вміст торф'яного залишку в торф'яній суміші повинен бути в діапазоні $15 \ldots 25 \%$. Мінімальний вміст деревини в композиції для вмісту торф'яного залишку в торф'яній суміші $15 \ldots 25 \%$ та теплоті згоряння сухого залишку $15 \ldots 17,6$ МДж/кг можна знайти за номограмою або залежністю (4). Наприклад, при вмісті залишку в торф'яній суміші $25 \%$, теплоті згоряння сухого залишку 16 МДж/кг, вміст деревини в композиційній суміші повинен становити не менше 23,5\%. Як видно 3 рис. 5 технологія виготовлення композиційних брикетів обмежена теплотою згоряння залишку $Q_{\text {зал }}^{c}>14$ МДж/кг, в іншому випадку слід використовувати наповнювач 3 вищою теплотою згоряння, наприклад лузгу соняшника.

\section{Висновки}

Найбільш енергетично та економічно обгрунтованою є технологія комплексної переробки торфу на паливо з екстракцією гумінових речовин з фрезерного торфу та польовим сушінням твердого залишку.

Втрату органічної складової у залишку торфу після екстракції запропоновано компенсувати домішкою деревинної чи рослинної біомаси. Для нормалізації якісних показників композиційного палива в торфосуміш рекомендується додавати деревину згідно розробленої номограми.

Вміст торф'яного залишку в торф' яній суміші повинен знаходитися в діапазоні $15 . .25 \%$, а деревини не перевищувати 40...\%.

У випадку значення теплоти згоряння залишку після екстракції $Q_{\text {зал }}^{c}<14$ МДж/кг, слід використовувати наповнювач 3 теплотою згоряння вище ніж у деревини, наприклад лузгу соняшника.

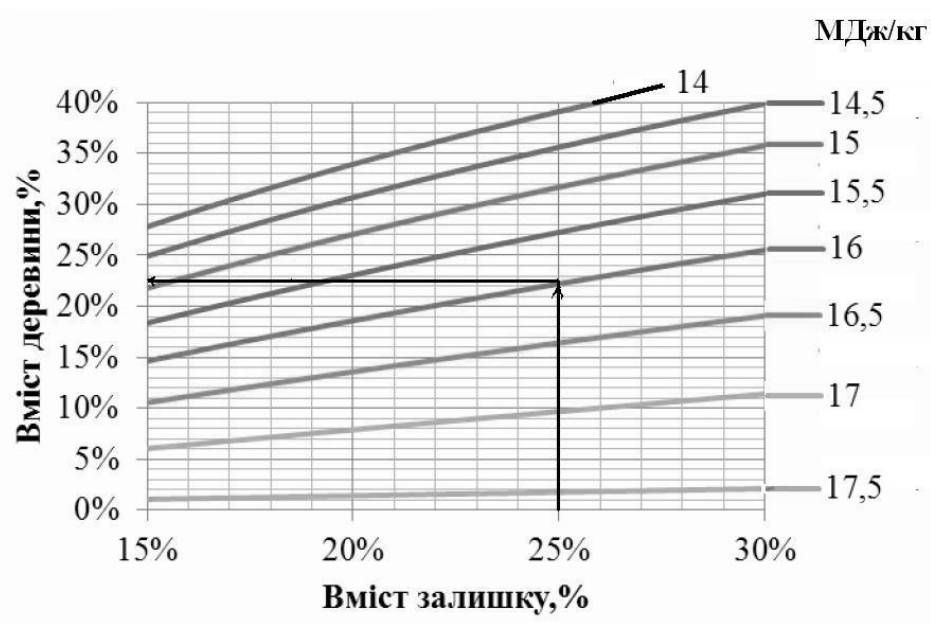

Рис. 5. Номограма залежності вмісту деревинної біомаси у торфосумімі для підвищення теплоти згоряння композиційних брикетів до нормованого значення від вмісту залишку. 


\section{ЛІТЕРАТУРА}

1. Смирнов В.И. "Технология и комплексная механизация торфяного производства" / В.И. Смирнов А.Н., Васильев А.Е., Афанасьев, А.Н.Болтушкин .- Тверь: ТГТУ, - 2007. - 240 с

2. Никифоров B.A. Разработка торфяных месторождений и механическая переработка торфа / В.А. Никифоров. - Мн.: Висшая школа, 1979. - $400 \mathrm{c}$.

3. Корінчук Д.М. Розробка композиційного палива на основі торфу і рослинної біомаси для використання в теплоенергетичних установках.: автореф. дис. канд.техн. наук: 05.14.06 / НАН України. - К., 2010. - 20 с.

4. Снєжкін Ю.Ф. Обгрунтування технології переробки торфу на паливо 3 вилученням гумінової складової / Ю.Ф.Снєжкін, Д.М. Корінчук, В.А. Михайлик. // Зб. матеріалів 2-го Міжнародного конгресу «Захист навколишнього середовища. Енергоощадність. Збалансоване природокористування.» - Львів: ТзОВ «ЗУЦК», 2012. - С. 78. 
SUBSTANTIATION OF TECHNOLOGY FOR COMPLEX PROCESSING OF PEAT FUEL WITH REMOVING HUMIC COMPONENT

\section{Korinchuk D.M.}

Institute of Engineering Thermophysics of the National Academy of Sciences of Ukraine, vul. Zhelyabova, 2a, Kyiv, 03680, Ukraine

The article is dedicated to substantiation of methods for combining production of humic fertilizer and peat composite fuel at a Peat plant using peat residue after extraction, milled peat and wood

The most energetically and economically feasible technology is complex processing of peat to fuel with extraction of humic substances from milled peat and field drying the solid residue.

The author offered to compensate a loss of organic components in a peat residue after extraction by adding woody or vegetable biomass. Adding wood into a peat mixes in compliance with developed nomogram is recommended for normalization of the quality indicators of composite fuel.

The content of peat residue in peat mix should be in the range of $15 \ldots 25 \%$, and for wood it should not exceed $40 \%$.

In the case of calorific value of residue after extraction is less than $14 \mathrm{MJ} / \mathrm{kg}$, filler with higher calorific value than calorific value of wood, such as sunflower husk, should be used.

References 3, figure 5.

Key words: milled peat, humic substances, biomass, composite fuel

1. Smirnov $V$. "Technology and complex mechanization of peat producwa" / VI Smirnov AN Vasiliev AE Afanasiev, A.N.Boltushkin., Tver: TGTU - 2007 - 240 p. (Rus.)

2. Nikiforov $V$. Development of peat deposits and mechanical Perera-processing peat / VA Nikiforov. Mn .: Visshaya School, 1979. - 400 p. (Rus.)

3. Korinchuk D. Development of composite fuel based on peat and vegetable biomass for using in heat-and-power engineering systems. : Thesis for the degree of candidate of technical science : 05.14.06 / NAS of Ukraine. - Kiev, 2010. - P. 20. (Ukr.)

4. Snyezhkin Yu. Substantiation of processing technology peat fuel with the removal of humic component / Yu.F.Snyezhkin, D.M.Korinchuk, V.A.Myhaylyk. // Collection. Materials 2nd International Congress "Environmental protection. Energy. Sustainable environmental management. "Lviv: LLC" ZUTSK ", 2012. - P. 79. (Ukr.)

Получено 18.05.2015 Received 18,05,2015 